\title{
Front Matter: Volume 10747
}

, "Front Matter: Volume 10747," Proc. SPIE 10747, Optical System Alignment, Tolerancing, and Verification XII, 1074701 (5 November 2018); doi:

$10.1117 / 12.2515813$

SPIE Event: SPIE Optical Engineering + Applications, 2018, San Diego, California, SPIE. United States 


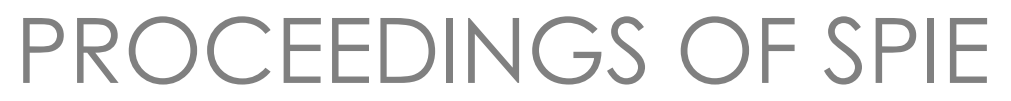

\section{Optical System Alignment, Tolerancing, and Verification XII}

José Sasián

Richard N. Youngworth

Editors

19-20 August 2018

San Diego, California, United States

Sponsored and Published by

SPIE 
The papers in this volume were part of the technical conference cited on the cover and title page. Papers were selected and subject to review by the editors and conference program committee. Some conference presentations may not be available for publication. Additional papers and presentation recordings may be available online in the SPIE Digital Library at SPIEDigitalLibrary.org.

The papers reflect the work and thoughts of the authors and are published herein as submitted. The publisher is not responsible for the validity of the information or for any outcomes resulting from reliance thereon.

Please use the following format to cite material from these proceedings:

Author(s), "Title of Paper," in Optical System Alignment, Tolerancing, and Verification XII, edited by José Sasián, Richard N. Youngworth, Proceedings of SPIE Vol. 10747 (SPIE, Bellingham, WA, 2018) Seven-digit Article CID Number.

ISSN: 0277-786X

ISSN: 1996-756X (electronic)

ISBN: 9781510620650

ISBN: 9781510620667 (electronic)

Published by

SPIE

P.O. Box 10, Bellingham, Washington 98227-0010 USA

Telephone +1 3606763290 (Pacific Time) · Fax +1 3606471445

SPIE.org

Copyright @ 2018, Society of Photo-Optical Instrumentation Engineers.

Copying of material in this book for internal or personal use, or for the internal or personal use of specific clients, beyond the fair use provisions granted by the U.S. Copyright Law is authorized by SPIE subject to payment of copying fees. The Transactional Reporting Service base fee for this volume is $\$ 18.00$ per article (or portion thereof), which should be paid directly to the Copyright Clearance Center (CCC), 222 Rosewood Drive, Danvers, MA 01923. Payment may also be made electronically through CCC Online at copyright.com. Other copying for republication, resale, advertising or promotion, or any form of systematic or multiple reproduction of any material in this book is prohibited except with permission in writing from the publisher. The CCC fee code is 0277$786 \mathrm{X} / 18 / \$ 18.00$.

Printed in the United States of America.

Publication of record for individual papers is online in the SPIE Digital Library.

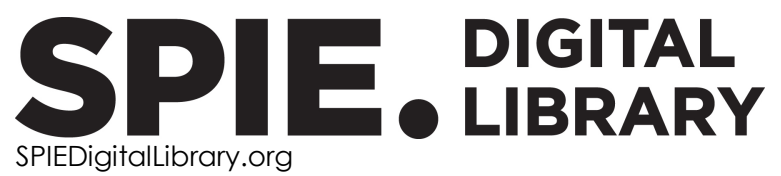

Paper Numbering: Proceedings of SPIE follow an e-First publication model. A unique citation identifier (CID) number is assigned to each article at the time of publication. Utilization of CIDs allows articles to be fully citable as soon as they are published online, and connects the same identifier to all online and print versions of the publication. SPIE uses a seven-digit CID article numbering system structured as follows:

- The first five digits correspond to the SPIE volume number.

- The last two digits indicate publication order within the volume using a Base 36 numbering system employing both numerals and letters. These two-number sets start with 00, 01, 02, 03, 04, 05, 06, 07, 08, 09, OA, OB ... 0Z, followed by 10-1Z, 20-2Z, etc. The CID Number appears on each page of the manuscript. 


\title{
Contents
}

\author{
$\checkmark \quad$ Authors \\ vii Conference Committee \\ ix Introduction
}

SESSION 1 OPTICAL ALIGNMENT

$1074702 \quad$ Alignment of a three-mirror telescope using the sine condition test [10747-1]

1074704 Assembly and testing of a large zoom lens for proton radiography (Invited Paper) [10747-3]

$1074705 \quad$ New technique of segments alignment in a large dimensions mirror [10747-4]

\section{SESSION 2 CALIBRATION, MEASUREMENT, AND VERIFICATION}

1074706 The measurement of the misalignment induced aberration of a miniature lens [10747-5]

1074707 Calibration methods for a dual-wavelength interferometer system [10747-6]

1074708 Experimental verification of compliant mirror wavefront correction using a single actuator [10747-7]

1074709 Application of adaptive photodetectors and the Talbot effect to measure the focal length of a lens [10747-8]

\section{SESSION $3 \quad$ INSTRUMENTS AND ALIGNMENT}

10747 OA Confocal microscopy for high-precision non-contact optical measurements [10747-9]

10747 OB Introduction to optical alignment techniques: a long-running SPIE short course (Invited Paper) [10747-10] 
10747 OC Assessing the W2-AM for use in profiling x-ray optics [10747-11]

10747 OD A novel mirror-mount design suitable for laboratory and OEM applications [10747-12]

\section{SESSION 4 OPTICAL TOLERANCING}

10747 OF A designer's point of view on integration of ANSI scratch and dig into ISO surface imperfections [10747-14]

10747 OG As-fab elements: design vs. reality [10747-15]

$10747 \mathrm{OH} \quad$ Increasing system stability with tighter tolerances following the Taguchi Robust Design approach on short-pulsed laser helical drilling of stainless steel [10747-16]

10747 Ol Towards euclidean auto-calibration of stereo camera arrays [10747-17]

10747 OJ Design of a SWIR optical zoom system for surveillance [10747-22]

\section{POSTER SESSION}

10747 OM Impact of assembly error of cascade prism on beam scanning precision [10747-20] 


\section{Authors}

Numbers in the index correspond to the last two digits of the seven-digit citation identifier (CID) article numbering system used in Proceedings of SPIE. The first five digits reflect the volume number. Base 36 numbering is employed for the last two digits and indicates the order of articles within the volume. Numbers start with 00, 01, 02, 03, 04, 05, 06, 07, 08, 09, OA, OB...0Z, followed by 10-1Z, 20-2Z, etc.

Brown, Thomas G., 07

Castle, Kenneth R., OB, OG

Chang, Hung-Sheng, 06

Choi, Hyun Chul, OJ

Clark III, James H., 08

Clark, Wyatt E., 08

Clayton, Daniel J., 04

Cornejo-Rodríguez, Alejandro, 05

Cserkaszky, Aron, 01

Densmore, Victor E., OG

DeWitt, Frank A., OD

Dubin, Matthew, 02

Ellis, Jonathan D., 07

Frayer, Daniel K., 04

Gillner, A., $\mathrm{OH}$

Gong, Wei, OM

Granados-Agustín, Fermín S., 05

Heilman, Micha, 08

Howlett, Isela D., OG

Jahn, Dirk, OF

Jana, Soumya, 0 I

Johnson, Micah A., OA

Kankelborg, Charles C., OA

Kara, Peter A., Ol

Kaufman, Morris I., 04

Kim, Hyun Kyu, OJ

Kim, Jung Hyun, OJ

Kuhn, William P., OC

Li, Anhu, OM

Liang, Chao-Wen, 06

Malone, Robert M., 04

Martini, Maria G., Ol

McGillivray, Kevin D., 04

Medicus, Kate, OG

Meuchel, Rubin, OA

Park, Soo Min, OJ

Penado, F. Ernesto, 08

Percino-Zacarías, María E., 05

Reddy, M. Shanmukh, 0 I

Richhariya, Ashutosh, 01

Rodríguez-Montero, Ponciano, 09

Shanor, Christopher M., OG

Smart, Roy, OA

Sommitz, David, 02

Stuhlinger, Tilman, OG

Tamboli, Roopak R., 0

Tangari Larrategui, Martin, 07

Tepichín-Rodríguez, Eduardo, 09

Vázquez y Montiel, Sergio, 05
Vupparaboina, Kiran K., 01

Zhang, Yanqi, 07

Zibner, F., OH 
Proc. of SPIE Vol. 10747 1074701-6

Downloaded From: https://www.spiedigitallibrary.org/conference-proceedings-of-spie on 26 Apr 2023 Terms of Use: https://www.spiedigitallibrary.org/terms-of-use 


\section{Conference Committee}

Program Track Chair

José Sasián, College of Optical Sciences, The University of Arizona (United States)

Conference Chairs

José Sasián, College of Optical Sciences, The University of Arizona (United States)

Richard N. Youngworth, Riyo LLC (United States)

Conference Program Committee

Matthew B. Dubin, College of Optical Sciences, The University of Arizona (United States)

Jonathan D. Ellis, College of Optical Sciences, The University of Arizona (United States)

Ulrike Fuchs, asphericon GmbH (Germany)

Sen Han, University of Shanghai for Science and Technology (China)

Marco Hanft, Carl Zeiss AG (Germany)

William P. Kuhn, Opt-E (United States)

Chao-Wen Liang, National Central University (Taiwan)

Norbert Lindlein, Friedrich-Alexander-Universität Erlangen-Nürnberg (Germany)

Robert M. Malone, Mission Support and Test Services, LLC (United States)

Raymond G. OhI IV, NASA Goddard Space Flight Center (United States)

Craig W. Pansing, Synopsys, Inc. (United States)

Robert E. Parks, Optical Perspectives Group, LLC (United States)

Brian C. Primeau, Ball Aerospace \& Technologies Corporation (United States)

Dmitry Reshidko, Microsoft Corporation (United States)

Martha Rosete-Aguilar, Centro de Ciencias Aplicadas y Desarrollo Tecnológico (Mexico)

Peng Su, ASML US, Inc. (United States) 
Session Chairs

1 Optical Alignment

Chao-Wen Liang, National Central University (Taiwan)

2 Calibration, Measurement, and Verification

Robert M. Malone, Mission Support and Test Services, LLC

(United States)

3 Instruments and Alignment

Sen Han, University of Shanghai for Science and Technology (China)

4 Optical Tolerancing

Dmitry Reshidko, Microsoft Corporation (United States) 


\section{Introduction}

The twelfth Optical System Alignment, Tolerancing, and Verification conference in 2018 was a great success. This year displayed an excellent variety of papers across the topics of alignment, tolerancing, and verification. We thank people for such excellent support for our conference's critical topics in optical engineering. We thank the effort rendered by our program committee, speakers, authors, attendees, and SPIE.

This year's conference had four strong sessions. The first session on Optical Alignment had papers on three-mirror telescope alignment using the sine condition, alignment with axicon gratings (invited), alignment and testing of a large format zoom lens for proton radiography (invited), a new technique for segment alignment in a large dimension mirror, and a related poster session paper on assembly error of cascade prism on beam scanning precision. The second session on Calibration, Measurement, and Verification had papers on the misalignment induced aberration of a miniature lens, calibration methods for a dual-wavelength interferometer system, experimental verification of compliant mirror wavefront correction, and adaptive photodetectors and the Talbot effect to measure lens focal length. The third session on Instruments and Alignment had papers on confocal microscopy for high precision optical measurements, optical alignment techniques short course (invited), assessing the W2-AM for use in profiling x-ray optics, and a novel mirror mount design. The last session on Optical Tolerancing had papers on fast tolerance analysis of optical systems for illumination, a designer's point of view on ANSI scratch and dig into ISO surface imperfections, as-fab elements: design vs. reality, increasing system stability with lower tolerances following the Taguchi Robust Design approach, Euclidean autocalibration of stereo camera arrays, and a related poster session paper on high angular tolerance of lensed fiber coupling. All four sessions were well attended, and the authors answered many questions the audience posed to them.

This successful conference will run again in 2019. We encourage everyone interested in any related research or development projects to please submit their work and attend the conference. Please feel free to contact us, or anyone on our program committee, if you have questions, suggestions, or requests for the conference. We look forward to another successful conference next year.

José Sasián Richard N. Youngworth 
Proc. of SPIE Vol. 10747 1074701-10

Downloaded From: https://www.spiedigitallibrary.org/conference-proceedings-of-spie on 26 Apr 2023 Terms of Use: https://www.spiedigitallibrary.org/terms-of-use 